\title{
Resveratrol and Vascular Function
}

\author{
Huige $\mathrm{Li}^{1, *(\mathbb{D})}$, Ning Xia ${ }^{1}$, Solveig Hasselwander ${ }^{1}$ and Andreas Daiber ${ }^{2, *(D)}$ \\ 1 Department of Pharmacology, Johannes Gutenberg University Medical Center, 55131 Mainz, Germany; \\ xianing@uni-mainz.de (N.X.); sohassel@uni-mainz.de (S.H.) \\ 2 Center for Cardiology, Cardiology I - Laboratory of Molecular Cardiology, Johannes Gutenberg University \\ Medical Center, 55131 Mainz, Germany \\ * Correspondence: huigeli@uni-mainz.de (H.L.); daiber@uni-mainz.de (A.D.)
}

Received: 25 March 2019; Accepted: 24 April 2019; Published: 30 April 2019

\begin{abstract}
Resveratrol increases the production of nitric oxide (NO) in endothelial cells by upregulating the expression of endothelial NO synthase (eNOS), stimulating eNOS enzymatic activity, and preventing eNOS uncoupling. At the same time, resveratrol inhibits the synthesis of endothelin- 1 and reduces oxidative stress in both endothelial cells and smooth muscle cells. Pathological stimuli-induced smooth muscle cell proliferation, vascular remodeling, and arterial stiffness can be ameliorated by resveratrol as well. In addition, resveratrol also modulates immune cell function, inhibition of immune cell infiltration into the vascular wall, and improves the function of perivascular adipose tissue. All these mechanisms contribute to the protective effects of resveratrol on vascular function and blood pressure in vivo. Sirtuin 1, AMP-activated protein kinase, and estrogen receptors represent the major molecules mediating the vascular effects of resveratrol.
\end{abstract}

Keywords: resveratrol; endothelium; endothelial nitic oxide synthase; sirtuin 1; cardiovascular disease; vascular function

\section{Resveratrol and its Molecular Targets}

The polyphenolic phytoalexin 3,5,4'-trihydroxy-trans-stilbene, better known under its trivial name resveratrol, can be found in numerous plants, such as white hellebore (Veratrum grandiflorum), mulberry (Morus rubra), peanut (Archis hypogaea), and grapes (Vitis vinifera) [1-3].

Since resveratrol gained popularity in 1992 [4], many targets responsible for its pharmacological effects have been identified $[5,6]$. These targets can be divided into those which directly interact with resveratrol (over 20) and those whose effects are indirectly changed, e.g., by modulation of their expression level [6]. Regarding vascular function, especially the estrogen receptor (ER), the NAD ${ }^{+}$-dependent, class III histone deacetylase sirtuin 1 (SIRT1), the nuclear factor-erythroid-derived 2-related factor-2 (Nrf2), and the AMP-activated protein kinase (AMPK) are of particular importance [7].

Resveratrol can directly activate SIRT1 on certain substrates [8,9]. Indirectly, resveratrol increases SIRT1 activity either through elevation of intracellular $\mathrm{NAD}^{+}$concentration, which is dependent on an inhibition of phosphodiesterase (PDE) [10,11], or through an enhancement of the binding of SIRT1 to lamin A, an endogenous SIRT1 activator [12]. In addition, the SIRT1-dependent effects of resveratrol in vivo are partially attributable to an upregulation of SIRT1 expression by the compound [13-15].

$\mathrm{Nrf2}$ is an indirect target protein of resveratrol. For its stimulation, concentrations of resveratrol lower than $1 \mu \mathrm{M}$ are sufficient (lower than that for SIRT1) [16], making its activation possible by using resveratrol as a dietary supplement [2]. Nrf2 interacts with antioxidant-response elements after its translocation to the nucleus. Here, it triggers the expression of phase II and antioxidant defense enzymes, like heme oxygenase-1 (HO-1) [16].

As mentioned before, resveratrol has been linked to PDE inhibition. One result of this effect is the phosphorylation of AMPK [11]. Another suggested pathway for AMPK activation is based on LKB1 
stimulation, e.g., by reduction of the intracellular ATP level $[17,18]$ or its deacetylation by SIRT1 $[19,20]$. Interestingly, AMPK and SIRT1 seem to function synergistically and bolster one another [21,22].

Resveratrol can directly bind the estrogen receptors (ERs) [23]. Very low (nanomolar) concentrations of resveratrol are enough for the ER-mediated stimulation of endothelial NO synthase (eNOS) [24,25]. Additionally, resveratrol-mediated ER-stimulation has also been linked to HO-1 upregulation as well as to Nox downregulation [26].

Also, the effects of resveratrol in vivo may also involve its actions on potassium channels [27-29], gut microbiota [30,31], and circadian gene expression [32].

\section{Effects of Resveratrol on Endothelial Cells}

The endothelium, consisting of a single layer of flat, longish endothelial cells, covers the inner walls of blood vessels. Vascular endothelial cells are unique in their property of holding Weibel-palade bodies, the depot for the Von Willebrand factor which is crucial for hemostasis maintenance. Apart from its function in maintaining blood coagulation and serving as starting point for angiogenesis, the endothelium also provides a semi-permeable barrier to regulate the transfer of electrolytes, macromolecules, and fluid between the intravascular and the extravascular space. Endothelial cells synthesize important vasoactive substances, including prostacyclin, NO, and the vasocontractile endothelin-1 (ET-1). Therefore, endothelial cells are key regulators of blood pressure and vascular tone [33].

\subsection{Resveratrol Enhances Endothelial NO Production}

Under physiological conditions, the endothelial NO synthase (eNOS) is the main producer of vascular NO [34]. It confers antithrombotic, antihypertensive, and anti-atherosclerotic effects [34,35]. Endothelial NO reaches the smooth muscle cells (SMC) by diffusion and causes vasodilation [36]. In the blood, eNOS-produced NO prevents platelet aggregation and adhesion. The anti-atherosclerotic properties of NO include the prevention of leukocyte adhesion to and migration into the vascular wall as well as the repression of low-density lipoprotein oxidation and the proliferation of vascular smooth muscle cells [34,37-39]. Suppression of the eNOS gene in mice leads to blood pressure elevation [40] and atherosclerosis aggravation [41,42]. Recently, it has been shown that eNOS-produced NO might be involved in mitochondrial biogenesis boosting [13] and could be partly responsible for the observed antiaging effects in calorie restriction studies [43]. In addition, it has been demonstrated that eNOS-knockout mice exhibit insulin resistance as well as hyperinsulinemia [44], while overexpression of eNOS protects mice fed with a high-fat diet (HFD) from pathological weight gain [45].

Resveratrol increases endothelial NO production through multiple mechanisms (Figure 1), including upregulation of eNOS expression, enhancement of eNOS enzymatic activity, and prevention of eNOS uncoupling [46].

\subsubsection{Resveratrol Upregulates eNOS Expression}

Resveratrol increases eNOS expression in endothelial cells. eNOS is constitutively expressed in the endothelium; its expression level changes in response to various stimuli and compounds $[35,47]$. We have previously shown that resveratrol itself [48] as well as resveratrol-containing red wines $[49,50]$ enhance eNOS expression in endothelial cells (Table 1). Interestingly, this phenomenon is not dependent on ERs but associates with transcriptional and posttranscriptional mechanisms [48]. In endothelial cells, knock-down of the SIRT1 gene via siRNA inhibits the up-regulation of eNOS by resveratrol treatment [13]. Correspondingly, an endothelium-specific overexpression of SIRT1 leads to elevated eNOS expression [51]. Therefore, resveratrol-induced up-regulation of eNOS is likely to be SIRT1-dependent. Strengthening this suggestion, we were recently able to show the involvement of FOXO factors as downstream targets of SIRT1 in resveratrol effects [14]. 


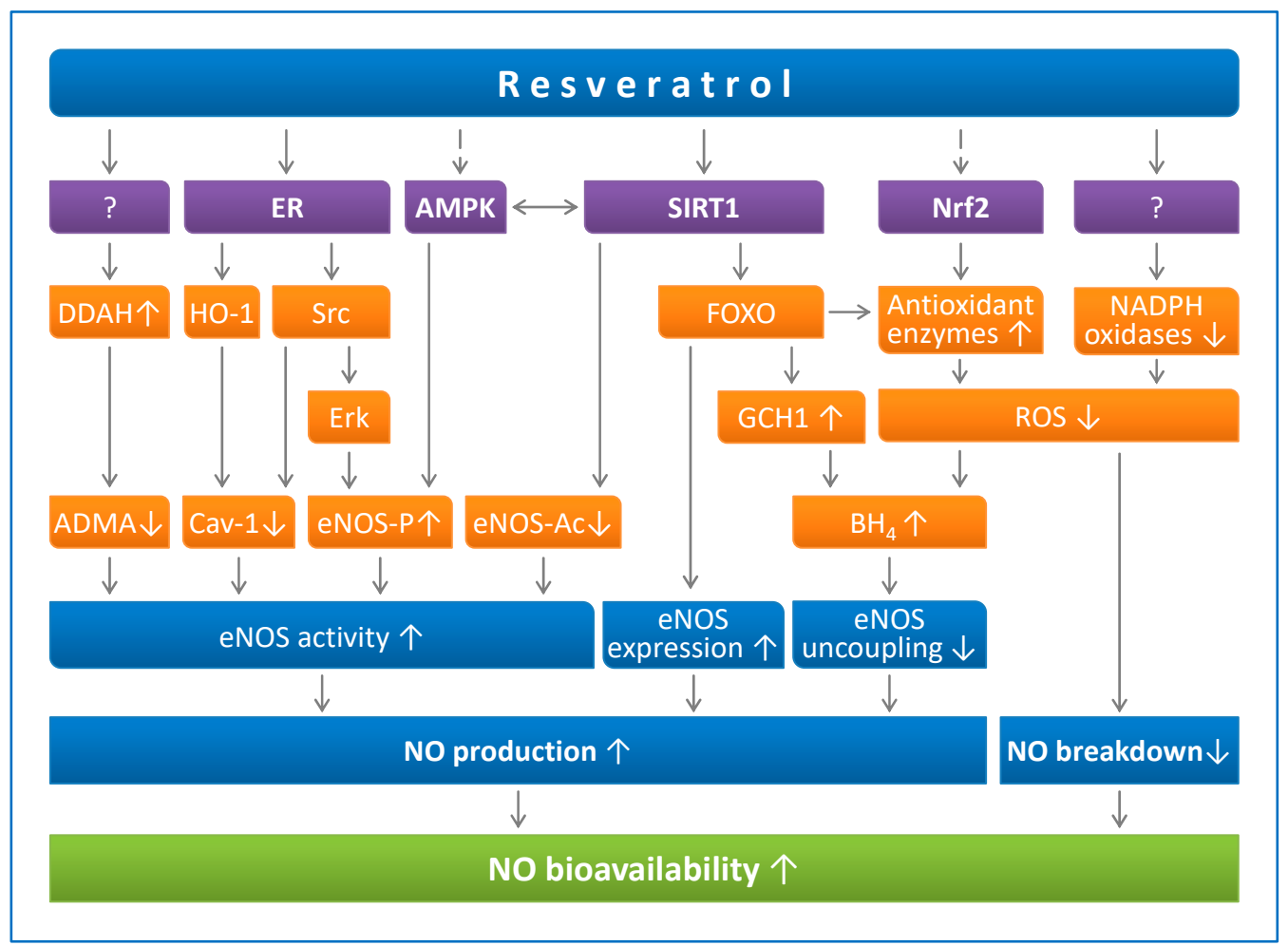

Figure 1. Resveratrol enhances NO production and prevents NO breakdown. Resveratrol can activate sirtuin 1 (SIRT1) directly (in a substrate-dependent manner) or indirectly (by either inhibiting phosphodiesterases or enhancing the effect of lamin A). SIRT1 stimulates endothelial NO synthase (eNOS) activity through deacetylation, enhances eNOS expression by deacetylating Forkhead box O (FOXO) transcription factors, and prevents eNOS uncoupling by upregulating GTP cyclohydrolase 1 (GCH1), the rate-limiting enzyme in tetrahydrobiopterin (BH4) biosynthesis. AMP-activated protein kinase (AMPK) and nuclear factor-erythroid-derived 2-related factor-2 (Nrf2) are indirect targets of resveratrol. AMPK phosphorylates eNOS at serine 1177. eNOS can also be phosphorylated by Erk1/2, which is stimulated by a pathway involving estrogen receptors (ER) and the tyrosine kinase Src. Caveolin-1 (Cav-1) is an eNOS-interacting protein that negatively regulates eNOS activity. Asymmetric dimethylarginine (ADMA) is an endogenous eNOS inhibitor that is degraded by dimethylarginine dimethylaminohydrolase (DDAH). The resveratrol targets for DDAH upregulation or for NADPH oxidase downregulation have not been identified so far. Reproduced from Xia et al. Molecules. 2014 [46], under the terms of the Creative Commons Attribution-Noncommercial License CC BY-NC.

\subsubsection{Resveratrol Increases eNOS Activity}

In addition to eNOS expressional upregulation, resveratrol also enhances enzymatic activity of eNOS through post-translational modifications. Phosphorylation of eNOS at Ser-1177 is an activating modification [52,53]. Resveratrol has been shown to increase eNOS Ser-1177 phosphorylation in cultured endothelial cells $[24,25]$. For this effect, resveratrol concentrations of the nanomolar range are sufficient. The underlying signaling pathway includes the estrogen receptor $\mathrm{ER} \alpha$, G-protein $\mathrm{G} \alpha$, caveolin-1 (Cav-1), the tyrosine kinase c-Src, and the MAP kinase Erk1/2 [24,25]. In concentrations of the micromolar range, phosphorylation of eNOS at the Ser-1177 by resveratrol also involves the activation of the AMPK $[54,55]$. Additionally, resveratrol enhances eNOS activity by inducing SIRT1-mediated deacetylation of eNOS at Lys-496 and Lys-506 [56,57].

An established endogenous eNOS inhibitor is asymmetric dimethylarginine (ADMA) [58]. Its degrading enzyme dimethylarginine dimethylaminohydrolase (DDAH) was found to be down-regulated by high concentrations of glucose, resulting in intracellular ADMA accumulation. This development, however, can be prevented by pre-treating of the cells with resveratrol [59]. 
Another negative regulator of eNOS is Cav-1 [60]. It was shown in vitro (endothelial cells $[25,61])$ and in vivo (rat heart $[62,63]$ ) that resveratrol targets these protein-protein interactions both by reduction of the Cav-1 expression level and by restriction of the Cav-1/eNOS association [62,63].

Table 1. Resveratrol increases NO production in endothelial cells.

\begin{tabular}{cccc}
\hline Cell Type & Effective Concentration & Effects & Reference \\
\hline HUVEC & $10-100 \mu \mathrm{M}$ & eNOS $\uparrow ;$ NO $\uparrow$ & {$[48]$} \\
EA.hy 926 & $10-100 \mu \mathrm{M}$ & eNOS (via SIRT1/FOXO) $\uparrow$; NO $\uparrow$ & {$[14,48]$} \\
HCAEC & $1-100 \mu \mathrm{M}$ & eNOS (via SIRT1) $\uparrow$ & {$[13]$} \\
HUVEC & $0.1 \mu \mathrm{M}$ & eNOS $\uparrow$; VEGF $\uparrow ; \mathrm{ET}-1 \downarrow$ & {$[33]$} \\
BAEC, HUVEC & $1-100 \mathrm{nM}$ & p-eNOS $\uparrow($ via ER $\alpha$ \& Erk1/2) & {$[24]$} \\
HUVEC & $1-100 \mu \mathrm{M}$ & p-eNOS $\uparrow($ via AMPK) & {$[54]$} \\
STA & $50 \mu \mathrm{M}$ & p-eNOS $\uparrow$ (via AMPK) & {$[55]$} \\
RAEC & $100 \mu \mathrm{M}$ & Ac-eNOS $\downarrow$ & {$[56]$} \\
\hline
\end{tabular}

Ac-eNOS; acetylated eNOS; BACE, bovine aortic endothelial cells; HCAEC, human coronary arterial endothelial cells; HUVEC, human umbilical vein endothelial cells; p-eNOS, phosphorylation of eNOS at serine 1177; STA, superior thyroid artery; RAEC, rat aortic endothelial cells; VEGF, vascular endothelial growth factor.

\subsubsection{Resveratrol Prevents eNOS Uncoupling}

Importantly, resveratrol also prevents eNOS uncoupling. This terminology describes the phenomenon of superoxide production by eNOS under pathological conditions [64-66]. Major mechanisms underlying eNOS uncoupling are the lack of the eNOS substrate L-arginine or the eNOS cofactor BH4 as well as eNOS S-glutathionylation $[38,64,66]$. Causes for BH4 insufficiency are its oxidation by potent oxidizing agents, such as peroxynitrite and superoxide [67-70]. This event and the following eNOS uncoupling though, can be prevented by resveratrol due to its antioxidant effects. Additionally, resveratrol boosts BH4 biosynthesis by enhancing the expression of GTP cyclohydrolase 1, an essential enzyme for $\mathrm{BH} 4$ production [71]. We previously described the vicious circle resulting from eNOS uncoupling leading to a potentiation of oxidative stress as a central mechanism adding to cardiovascular diseases [64-66]. Resveratrol intervenes in this circle by avoiding eNOS uncoupling and excess oxidative stress (Table 2).

Table 2. Resveratrol reduces oxidative stress in endothelial cells.

\begin{tabular}{cccc}
\hline Cell Type & Effective Concentration & Effects & Reference \\
\hline HUVEC & $1-100 \mu \mathrm{M}$ & NADPH oxidase activity & {$[72]$} \\
HUVEC & $10-100 \mu \mathrm{M}$ & SOD1 $\uparrow ;$ GPx1 $\uparrow ;$ Nox4 $\downarrow$ & {$[73]$} \\
EA.hy 926 & $100 \mu \mathrm{M}$ & SOD1 $\uparrow ;$ SOD2 $\uparrow ;$ SOD3 $\uparrow ;$ GPx1 $\uparrow$ catalase $\uparrow$ & {$[71]$} \\
RAS & $1-100 \mu \mathrm{M}$ & GPx1 $\uparrow$ catalase $\uparrow$ & {$[74]$} \\
HCAEC & $1-10 \mu \mathrm{M}$ & SOD2 $\uparrow ;$ SIRT1 $\uparrow ;$ GSH $\uparrow ;$ mtROS $\downarrow$ & {$[75]$} \\
HCAEC & $0.1-100 \mu \mathrm{M}$ & Nrf $2 \uparrow ;$ NQO1 $\uparrow ;$ GCLC $\uparrow ;$ HO- $1 \uparrow$ & {$[16]$} \\
\hline
\end{tabular}

GCLC, $\gamma$-glutamylcysteine synthetase; GPx1, glutathione peroxidase 1; HCAEC, human coronary arterial endothelial cells; HO-1, heme oxygenase-1; HUVEC, human umbilical vein endothelial cells; NQO1, $\mathrm{NAD}(\mathrm{P}) \mathrm{H}$ :quinone-oxidoreductase 1; RAS, rat aortic segments; mtROS, mitochondrial reactive oxygen species.

\subsection{Resveratrol Reduces Endothelial Oxidative Stress}

Since the capacity of resveratrol to directly eliminate free radicals is lower than that of already established antioxidant reagents, the means by which it diminishes oxidative stress in vivo are more likely due to its ability to regulate gene expression (Figure 2) [15]. Indeed, resveratrol is a potent gene regulator [76]. At a concentration of $0.1 \mu \mathrm{M}$, resveratrol has been shown to upregulate 127 genes and downregulate 233 genes in cultured human umbilical vein endothelial cells (HUVEC) [33]. 


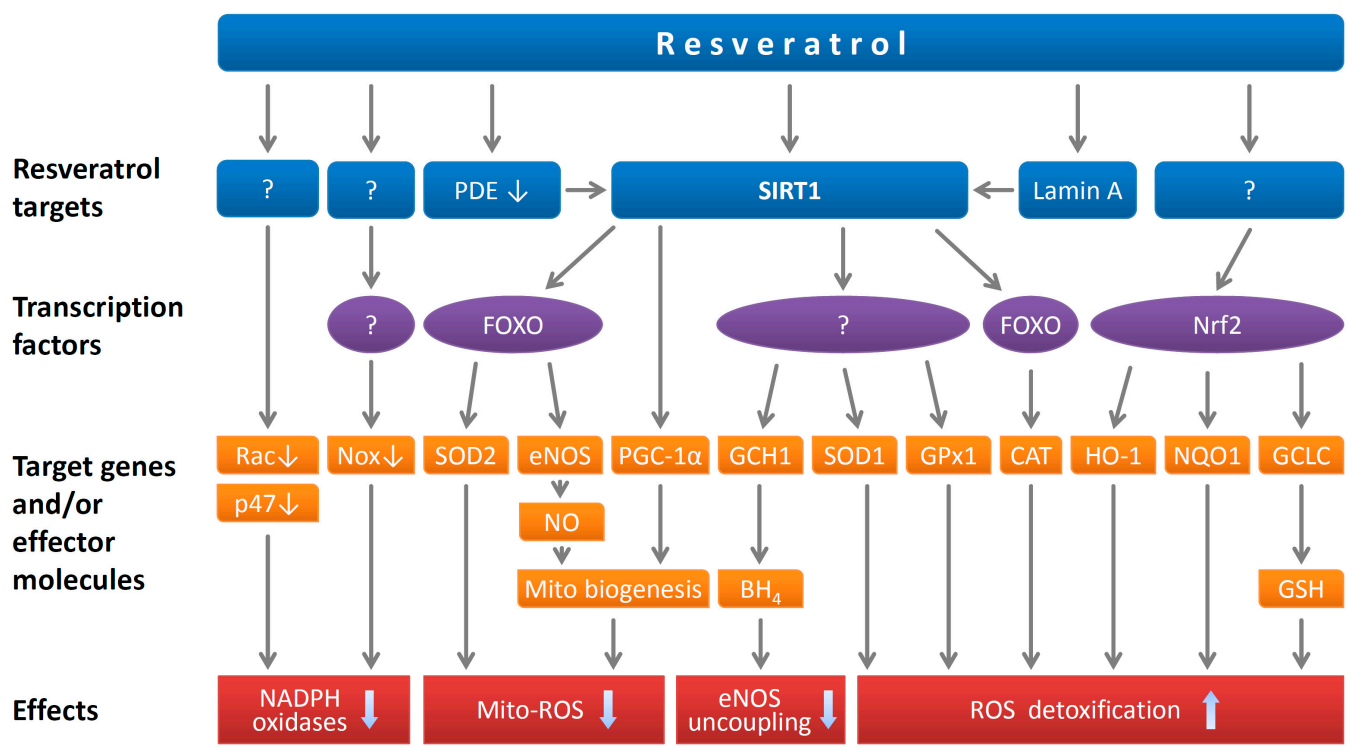

Figure 2. Antioxidant effects of resveratrol. Resveratrol inhibits NADPH oxidase-mediated reactive oxygen species (ROS) production by downregulation of the catalytic subunits (NOX proteins) and by inhibiting membrane translocation of Rac1 and inhibiting phosphorylation of p47phox. Resveratrol directly activates SIRT1 on certain substrates. It can also activate SIRT1 indirectly by potentiating the activation effect of lamin A or via a pathway involving phosphodiesterase (PDE) inhibition that leads to elevation of cellular $\mathrm{NAD}^{+}$. Among the established SIRT1 targets, FOXO transcription factors contribute to the antioxidant effects of resveratrol by upregulating antioxidant enzymes (e.g., SOD1, SOD2, GPx1 and catalase, CAT) and eNOS. SIRT1 inhibits mitochondrial superoxide production by stimulating mitochondrial biogenesis, which is mediated by PGC-1 $\alpha$ deacetylation and by NO-dependent mechanisms. The upregulation of GCH1 leads to enhancement of BH4 biosynthesis and prevention of eNOS uncoupling. In addition, resveratrol upregulates a number of antioxidant enzymes by activating Nrf2. Reproduced from Xia et al. Br. J. Pharmacol. 2017 [15] with permission. Copyright (C) 2017 John Wiley and Sons (Hoboken, NJ, USA).

In cultured endothelial cells, resveratrol enhances the expression of phase 2 enzymes and antioxidant enzymes, including $\mathrm{NAD}(\mathrm{P}) \mathrm{H}$ :quinone-oxidoreductase 1 (NQO1), $\gamma$-glutamylcysteine synthetase (GCLC), HO-1, SOD1, SOD2, glutathione peroxidase 1 (GPx1), and catalase [16,71,73,74]. The expression [71,73] and activity [72] of NADPH oxidases, major ROS-producing enzymes in endothelial cells, are reduced by resveratrol (Table 2). Furthermore, resveratrol improves mitochondrial biogenesis and thus diminishes mitochondrial superoxide production [75].

SIRT1 and Nrf2 play important roles in the expressional regulation of redox genes by resveratrol [15]. Resveratrol-induced upregulation of SOD1, SOD2, GPx1, and catalase requires SIRT1, whereas Nrf2 is responsible for the upregulation of HO-1, NQO1, and GCLC by resveratrol [16,71,73-75].

\subsection{Resveratrol Reduces Endothelin-1 Synthesis}

ET-1 is a highly potent vasoconstrictor [33]. Overproduction of ET-1 is implicated in the development of vascular disease and atherosclerosis [77]. Interestingly, resveratrol has been shown to reduces ET-1 synthesis in endothelial cells and smooth muscle cells (Table 3), as well as in the plasma of resveratrol-treated rabbits [78]. It is conceivable that both the enhanced production of $\mathrm{NO}$ and reduced synthesis of ET-1 are involved in the vasodilation and blood pressure reduction by resveratrol in vivo. 
Table 3. Resveratrol reduces endothelin-1 synthesis.

\begin{tabular}{cccc}
\hline Cell Type & Effective Concentration & Effects & Reference \\
\hline HUVEC & $1-100 \mu \mathrm{M}$ & ROS $\downarrow$; p-Erk1/2 $\downarrow ;$ strain-induced ET-1 $\downarrow$ & {$[72]$} \\
HUVEC & $0.1 \mu \mathrm{M}$ & ET-1 $\downarrow ;$ eNOS $\uparrow ;$ VEGF $\uparrow$ & {$[79]$} \\
HUVEC & $30 \mu \mathrm{M}$ & ET- $1 \downarrow ;$ ECE- $1 \downarrow$ & {$[80]$} \\
HASMC & $100 \mu \mathrm{M}$ & $\mathrm{H}_{2} \mathrm{O}_{2}$-induced ET- $1 \downarrow ;$ & {$[81]$} \\
RASMC & $10-100 \mu \mathrm{M}$ & AngII-induced ET- $1 \downarrow ;$ proliferation $\downarrow$ & {$[82]$} \\
\hline
\end{tabular}

AngII, angiotensin II; ECE-1, endothelin-converting enzyme-1; HASMC, human aortic smooth muscle cells; HUVEC, human umbilical vein endothelial cells; RASMC, rat aortic smooth muscle cells; ROS, reactive oxygen species.

\section{Effects of Resveratrol on Vascular Smooth Muscle Cells}

\subsection{Resveratrol Reduces Oxidative Stress in Smooth Muscle Cells}

Resveratrol has been shown to produce biphasic effects on HO-1 expression in human aortic SMC in a NF- $\kappa \mathrm{B}-$ dependent manner, with a HO-1 induction at low concentrations of resveratrol $(1-10 \mu \mathrm{M})$ and a reduction at high concentrations of resveratrol $(\geq 20 \mu \mathrm{M})$ [83]. This phenomenon has not been observed in later studies. In in rat aortic SMC, resveratrol (1-30 $\mu \mathrm{M})$ causes a concentration-dependent upregulation of HO-1 mediated by Nrf2 [84].

Treatment of cultured rat aortic SMC with resveratrol $(25-100 \mu \mathrm{M})$ leads to upregulation of SOD, catalase, glutathione, glutathione reductase, glutathione peroxidase, glutathione S-transferase (GST) and NOQ1 [85]. GST and NQO1 are typical phase 2 enzymes responsible for detoxification of both ROS and electrophilic xenobiotics [85]. The induction of such cellular antioxidants and phase 2 enzymes by resveratrol protects the cells from oxidative stress and oxidants-induced cytotoxicity (Table 4).

\subsection{Resveratrol Inhibits Smooth Muscle Cell Proliferation}

Normally differentiated vascular smooth muscle cells (VSMC) express a specific set of contractile proteins, have low synthetic activity, and proliferate slowly [86]. Upon stimulation by growth factor or in response to vascular injury, VSMC can change their phenotype through de-differentiation, proliferation, and migration to the site of injury [86]. While the phenotypic plasticity in VSMC is essential for the maintenance and repair of the vasculature, excessive proliferation of VSMC promotes the development of atherosclerosis, restenosis, and pulmonary hypertension [86,87].

Resveratrol has been shown to inhibit VSMC proliferation induced by various mitogens (Table 4). Depending on the mitogenic stimuli, the molecular mechanisms include inhibition of PI3K/Akt/mTOR pathway or cell cycle arrest (Table 4). In addition, antiproliferative effects in VSMC have also been reported for the resveratrol tetramer vitisin B [88] and for pterostilbene, a natural dimethylated analog of resveratrol [89]

Oral administration of resveratrol has been shown to significantly suppress intimal hyperplasia in mouse models of wire-injured arteries [84,90]. Intraperitoneal injection of resveratrol also inhibited the development of intimal hyperplasia in the rat carotid artery injury model [91].

Because of the low bioavailability of systemically administrated resveratrol, local delivery may represent a promising method improving the in vivo efficacy of the compound. Resveratrol coated on a stent reduced stenosis in rat carotid artery by $65 \%$ [92]. In a recent study of rat carotid balloon angioplasty, resveratrol was applied in Pluronic gel around the injured artery [93]. Strikingly, periadventitial application of resveratrol significantly improved all three major pathologies contributing to restenosis: VSMC hyperplasia in the intima, impairment of re-endothelialization, and constrictive remodeling [93]. Periadventitial delivery of resveratrol produced a much greater neointima-inhibiting effect (86\%) than systemic resveratrol administration reported in previous studies. Moreover, post-surgery endothelial recovery was accelerated by resveratrol without causing constrictive remodeling [93]. These are compelling advantages over drug-eluting stents currently used in clinical settings. 
Table 4. Effects of resveratrol in vascular smooth muscle cells (VSMC).

\begin{tabular}{|c|c|c|c|}
\hline Cell Type & Effective Concentration & Effects & Reference \\
\hline VSMC & $50-100 \mu \mathrm{M}$ & Serum- and PDGF-induced proliferation $\downarrow$ & [94] \\
\hline RASMC & $0.1-1 \mu \mathrm{M}$ & AGEs-stimulated proliferation $\downarrow$ & [95] \\
\hline RASMC & $25-50 \mu \mathrm{M}$ & AngII-induced proliferation $\downarrow ;$ p-Akt $\downarrow$ & [96] \\
\hline HASMC & $1-100 \mu \mathrm{M}$ & $\begin{array}{l}\text { Proliferation } \downarrow \text {; p } 53 \uparrow \text {; cell cycle arrest without } \\
\text { apoptosis at } 6.25-12.5 \mu \mathrm{M} \text {; apoptosis at } 25 \mu \mathrm{M}\end{array}$ & [97] \\
\hline RASMC & $50-100 \mu \mathrm{M}$ & Serum-induced proliferation $\downarrow$; cell cycle arrest & [98] \\
\hline RASMC & $10-100 \mu \mathrm{M}$ & AngII-induced proliferation $\downarrow ;$ ET- $1 \downarrow$ & [82] \\
\hline BASMC & $10-100 \mu \mathrm{M}$ & Serum-induced proliferation $\downarrow$; cell cycle arrest & [99] \\
\hline HASMC & $20-100 \mu \mathrm{M}$ & TNF- $\alpha$-induced proliferation $\downarrow$; cell cycle arrest & [100] \\
\hline HASMC & $10-50 \mu \mathrm{M}$ & Proliferation $\downarrow ; \mathrm{p} 53 \uparrow ; \mathrm{HSP} 27 \uparrow$ & [101] \\
\hline RFSMC & $25-50 \mu \mathrm{M}$ & $\begin{array}{l}\text { oxLDL-induced proliferation } \downarrow ; \\
\text { PI3K/Akt/mTOR/p70S6K } \downarrow\end{array}$ & {$[102]$} \\
\hline HASMC & $5-20 \mu \mathrm{M}$ & PI3K activity $\downarrow$; proliferation $\downarrow$ & [103] \\
\hline RASMC & $3-100 \mu \mathrm{M}$ & Nrf2 $\uparrow, \mathrm{HO}-1 \uparrow$; cyclin $\mathrm{D} \downarrow$, proliferation $\downarrow$ & [84] \\
\hline HVSMC & $3-100 \mu \mathrm{M}$ & $\begin{array}{l}\text { Differentiation of de-differentiated VSMC to } \\
\text { the contractile phenotype }\end{array}$ & [86] \\
\hline RASMC & $50 \mu \mathrm{M}$ & $\begin{array}{l}\text { TGF- } \beta \text {-stimulated SMC de-differentiation } \downarrow ; \\
\text { p-Akt } \downarrow ; \text { p-mTOR } \downarrow ; \text { KLF5 } \downarrow\end{array}$ & [93] \\
\hline
\end{tabular}

AGEs, advanced glycation end-products; AngII, angiotensin II; BASMC, bovine aortic smooth muscle cells; HASMC, human aortic smooth muscle cells; HVSMC, human vascular smooth muscle cells; RASMC, rat aortic smooth muscle cells; RFSMC, rabbit femoral smooth muscle cells.

\subsection{Resveratrol Prevents Arterial Stiffness and Vascular Remodeling}

In addition to inhibition of VSMC proliferation, resveratrol also prevents vascular remodeling and arterial stiffness. In cultured rat aortic SMC stimulated with advanced glycation end-products (AGEs), resveratrol reduces TGF- $\beta 1$ expression and collagen synthesis [95]. In human VSMC, TNF- $\alpha$-induced expression of matrix metalloproteinase (MMP)-9 is inhibited by resveratrol [100].

Resveratrol has been shown to prevent high-fat, high-sucrose diet-induced arterial stiffness in mice [104]. This effect is likely to be mediated by SIRT1, because similar effects can be achieved with SIRT1 activators or by global SIRT1 overexpression [104]. Interestingly, overnight fasting acutely decreased arterial stiffness in wildtype mice but not in mice lacking SIRT1 in VSMC. Conversely, VSMC-specific SIRT1 overexpression prevented diet-induced arterial stiffness. The antistiffness effect of SIRT1 has been attributable to its anti-inflammatory and antioxidant properties mediated by NF-KB inhibition and downregulation of VCAM-1 and p47phox [104].

Resveratrol downregulates angiotensin II (AngII) type 1 receptor expression in VSMC through SIRT1 activation [105]. Moreover, resveratrol treatment decreases serum AngII level and the aortic expression of prorenin receptor (PRR) and angiotensin converting enzyme (ACE) and increases serum Ang(1-7) level and the expression of ACE2, AngII type 2 receptor (AT2R), and Mas receptor (MasR). These mechanisms (modulation of the renin-angiotensin system) have been made responsible for the protective effects of resveratrol on aging-induced vascular fibrosis [106] and kidney fibrosis [107].

\section{Effects of Resveratrol on Immune Cells}

Although leukocytes do not belong to the resident cells of the vascular wall, they contribute to the pathogenesis of cardiovascular disease [38]. Activated endothelial cells express adhesion molecules on their surface, leading to cell-cell interaction and immune cell infiltration into the vascular wall [108]. Resveratrol modulates the function of immune cells, including $\mathrm{CD}^{+} / \mathrm{CD}^{+} \mathrm{T}$ cells [109], regulatory T cells [110], natural killer (NK) cells [111], polymorphonuclear leukocytes [109], and monocytes $[110,112]$.

Resveratrol prevents the interaction between immune cells and endothelial cells. On the one hand, resveratrol (10-100 $\mu \mathrm{M})$ inhibits the expression and binding activity of chemokine receptors on leukocytes, e.g., CCR2 on monocytes [110]. On the other hand, resveratrol $(0.1-1 \mu \mathrm{M})$ also reduces 
the expression of adhesion molecules on endothelial cells [113]. Reduced macrophage infiltration and ameliorated vascular inflammation by resveratrol have also been demonstrated in vivo [114].

\section{Effects of Resveratrol on PVAT}

The perivascular adipose tissue (PVAT) is now considered an important regulator of vascular function by secreting a large number of vasoactive substances, including NO [115,116]. We have recently seen that the importance of PVAT-eNOS may even exceed that of endothelial eNOS under certain conditions [117]. In the thoracic aorta of diet-induced obese mice, for example, vascular dysfunction can only be observed if PVAT is kept in place. In aortae without PVAT of mice with obesity, vascular function remains normal $[117,118]$. This observation has led to the hypothesis that the reduction of NO-dependent vasodilation in obese mice is not due to a dysfunction of eNOS in the endothelium but in the PVAT [117]. Indeed, vascular function of the obese mice can be normalized by pharmacological improvements of PVAT-eNOS function [117,118].

Interestingly, resveratrol has been shown to improve PVAT function $[119,120]$. The acetylcholineinduced relaxation of aortae from normal rats is inhibited by conditioned media derived from PVAT of rats fed with fructose [119] or HFD [120]. The fructose- and HFD-induced PVAT dysfunction is largely reversed by an oral treatment with resveratrol $(20 \mathrm{mg} / \mathrm{kg}$ for 8 weeks $)[119,120]$. Similar PVAT dysfunction can be induced by an in vitro incubation of PVAT with palmitic acid. The palmitic acid-induced PVAT dysfunction is normalized by resveratrol $(10 \mu \mathrm{M})$, an effect that is prevented by either the AMPK inhibitor compound C or the SIRT1 inhibitor nicotinamide [119]. Because these experiments are performed using PVAT-derived conditioned media, the observed protective effects of resveratrol can be clearly attributed to PVAT.

\section{Effects of Resveratrol on Vascular Function and Blood Pressure in Vivo}

Antihypertensive effects of resveratrol have been observed in several animal models [7,121,122]. These include genetic hypertension (e.g., spontaneously hypertensive rats [SHR]) [123,124], AngII-induced hypertension [124], renal models of hypertension [125,126], DOCA salt hypertension [127], programmed hypertension [128] and diet-induced metabolic syndromes [129-131]. Increased endothelial NO production, reduced vascular oxidative stress, and the resulting improvement of vascular function are likely the major molecular mechanisms underlying the blood pressure-lowering effects of resveratrol (Table 5).

Interestingly, fecal microbiome transplants from resveratrol-treated healthy mice reduce the systolic blood pressure and left ventricular mass of hypertensive mice [30].

Table 5. Resveratrol reduces blood pressure in animal models.

\begin{tabular}{|c|c|c|c|}
\hline Model & Resveratrol dose & Effects & Reference \\
\hline SHR & $\begin{array}{l}5 \mathrm{mg} / \mathrm{kg}(50 \mathrm{mg} / \mathrm{L} \text { in drinking } \\
\text { water) for } 10 \text { weeks }\end{array}$ & $\begin{array}{c}\mathrm{BP} \downarrow ; \mathrm{ROS} \downarrow ; 3-\mathrm{NT} \downarrow ; \mathrm{EF} \uparrow ; \mathrm{eNOS} \uparrow ; \\
\text { eNOS uncoupling } \downarrow\end{array}$ & [123] \\
\hline SHR & $\begin{array}{c}146 \mathrm{mg} / \mathrm{kg}(4 \mathrm{~g} / \mathrm{kg} \text { mixed in chow }) \\
\text { for } 5 \text { weeks }\end{array}$ & $\begin{array}{c}\mathrm{BP} \downarrow ; \mathrm{FMD} \uparrow ; \mathrm{p}-\mathrm{AMPK} \uparrow ; \\
\text { p-eNOS} \uparrow ; 4-\mathrm{HNE} \downarrow\end{array}$ & [124] \\
\hline AngII-infused mouse & $\begin{array}{c}320 \mathrm{mg} / \mathrm{kg}(4 \mathrm{~g} / \mathrm{kg} \text { mixed in chow }) \\
\text { for } 2 \text { weeks }\end{array}$ & $\begin{array}{l}\mathrm{BP} \downarrow ; \mathrm{FMD} \uparrow ; \mathrm{p}-\mathrm{AMPK} \uparrow ; \\
\text { p-eNOS} \uparrow ; 4-\mathrm{HNE} \downarrow\end{array}$ & [124] \\
\hline Partially nephrectomized rats & $\begin{array}{c}50 \mathrm{mg} / \mathrm{kg} / \text { day mixed in diet for } \\
4 \text { weeks }\end{array}$ & $\mathrm{BP} \downarrow ; \mathrm{NO} \uparrow ; \mathrm{ET}-1 \downarrow ; \mathrm{AngII} \downarrow$ & [125] \\
\hline Two-kidney, one-clip rats & $10 \mathrm{mg} / \mathrm{kg}$ i.p. for 6 weeks & $\begin{array}{l}\mathrm{BP} \downarrow ; \mathrm{EF} \uparrow ; \text { plasma TAC } \uparrow ; \mathrm{NO} \uparrow \text {; } \\
\text { tissue } \mathrm{SOD} \uparrow \text {, catalase } \uparrow, \mathrm{GSH} \uparrow \\
\mathrm{MDA} \downarrow \text { cardiac hypertrophy } \downarrow\end{array}$ & [126] \\
\hline DOCA salt & $1 \mathrm{mg} / \mathrm{kg}$ by gavage for 32 days & $\mathrm{BP} \downarrow ; \mathrm{EF} \uparrow$ & [127] \\
\hline Zucker rats & $10 \mathrm{mg} / \mathrm{kg}$ by gavage for 8 weeks & $\begin{array}{l}\mathrm{BP} \downarrow ; \mathrm{eNOS} \uparrow ; \mathrm{TG} \downarrow ; \mathrm{TC} \downarrow ; \\
\quad \text { insulin } \downarrow ; \text { leptin } \downarrow\end{array}$ & [132] \\
\hline HFD-fed female rats & $\begin{array}{l}20 \mathrm{mg} / \mathrm{kg} / \text { day mixed with diet for } \\
\text { 8 weeks }\end{array}$ & $\mathrm{BP} \downarrow ; \mathrm{EF} \uparrow$ & [129] \\
\hline Fructose-fed rats & $10 \mathrm{mg} / \mathrm{kg}$ by gavage for 45 days & $\begin{array}{c}\text { BP } \downarrow ; \text { cardiac hypertrophy } \downarrow \\
\text { eNOS } \uparrow ; \text { TBARS } \downarrow\end{array}$ & [130] \\
\hline
\end{tabular}


Table 5. Cont.

\begin{tabular}{cccc}
\hline Model & Resveratrol dose & Effects & Reference \\
\hline HFCS-induced MetS in rats & $5 \mathrm{mg} /$ day $(50 \mathrm{mg} / \mathrm{L}$ in drinking & wPater) for 10 weeks $\downarrow ; \mathrm{TG} \downarrow ; \mathrm{EF} \uparrow ;$ p-eNOS $\uparrow ; \mathrm{ROS} \downarrow$ & {$[131]$} \\
$\begin{array}{c}\text { Ovariectomized rats } \\
\begin{array}{c}\text { Obese rats programmed by } \\
\text { early weaning }\end{array}\end{array}$ & $5 \mathrm{mg} / \mathrm{kg}$ by gavage for 3 weeks & $\mathrm{BP} \downarrow ; \mathrm{EF} \uparrow$ & {$[133]$} \\
\hline
\end{tabular}

3-NT, 3-nitrotyrosine; 4-HNE, 4-hydroxy-2-nonenal; BP, blood pressure; EF, endothelial function; HFCS, high-fructose corn syrup; HFD, high-fat diet; LDL, low-density lipoprotein; MDA, malondialdehyde; MetS, metabolic syndrome; SHR, spontaneously hypertensive rats; TAC, total antioxidant capacity; TBARS, thiobarbituric acid reactive substances; TC, total cholesterol; TG, triglycerides.

\section{Conclusions}

Resveratrol increases endothelial NO production, decreases ET-1 synthesis, reduces vascular oxidative stress, and prevents smooth muscle proliferation, vascular remodeling, and arterial stiffness. In addition, resveratrol also inhibits immune cells infiltration into the vascular wall and mitigates vascular inflammation. All these mechanisms contribute to the in vivo effects of resveratrol on vascular function and blood pressure.

Author Contributions: H.L. and A.D. drafted the manuscript. N.X. and S.H. made critical revisions.

Funding: Original works from the authors' laboratory contributing to this review were supported by grants LI-1042/1-1 and LI-1042/3-1 from the Deutsche Forschungsgemeinschaft (DFG) and the intramural fund (Stufe I) of the Johannes Gutenberg University Medical Center Mainz. A.D. and H.L. were supported by research grants from the Boehringer Ingelheim Foundation for the collaborative research consortium "Novel and neglected cardiovascular risk factors: molecular mechanisms and therapeutic implications".

Conflicts of Interest: The authors declare no conflict of interest.

\section{References}

1. Aggarwal, B.B.; Bhardwaj, A.; Aggarwal, R.S.; Seeram, N.P.; Shishodia, S.; Takada, Y. Role of resveratrol in prevention and therapy of cancer: Preclinical and clinical studies. Anticancer Res. 2004, 24, 2783-2840.

2. Baur, J.A.; Sinclair, D.A. Therapeutic potential of resveratrol: The in vivo evidence. Nat. Rev. Drug Discov. 2006, 5, 493-506. [CrossRef] [PubMed]

3. Gupta, S.C.; Kannappan, R.; Reuter, S.; Kim, J.H.; Aggarwal, B.B. Chemosensitization of tumors by resveratrol. Ann. N. Y. Acad. Sci. 2011, 1215, 150-160. [CrossRef] [PubMed]

4. Catalgol, B.; Batirel, S.; Taga, Y.; Ozer, N.K. Resveratrol: French paradox revisited. Front. Pharmacol. $2012,3,141$. [CrossRef] [PubMed]

5. Pirola, L.; Frojdo, S. Resveratrol: One molecule, many targets. IUBMB Life 2008, 60, 323-332. [CrossRef] [PubMed]

6. Harikumar, K.B.; Aggarwal, B.B. Resveratrol: A multitargeted agent for age-associated chronic diseases. Cell Cycle 2008, 7, 1020-1035. [CrossRef] [PubMed]

7. Li, H.; Xia, N.; Forstermann, U. Cardiovascular effects and molecular targets of resveratrol. Nitric Oxide 2012, 26, 102-110. [CrossRef] [PubMed]

8. Hubbard, B.P.; Gomes, A.P.; Dai, H.; Li, J.; Case, A.W.; Considine, T.; Riera, T.V.; Lee, J.E.; E, S.Y.; Lamming, D.W.; et al. Evidence for a common mechanism of SIRT1 regulation by allosteric activators. Science 2013, 339, 1216-1219. [CrossRef]

9. Howitz, K.T.; Bitterman, K.J.; Cohen, H.Y.; Lamming, D.W.; Lavu, S.; Wood, J.G.; Zipkin, R.E.; Chung, P.; Kisielewski, A.; Zhang, L.L.; et al. Small molecule activators of sirtuins extend Saccharomyces cerevisiae lifespan. Nature 2003, 425, 191-196. [CrossRef] [PubMed]

10. Alexander, S.P.; Fabbro, D.; Kelly, E.; Marrion, N.; Peters, J.A.; Benson, H.E.; Faccenda, E.; Pawson, A.J.; Sharman, J.L.; Southan, C.; et al. The Concise Guide to PHARMACOLOGY 2015/16: Enzymes. Br. J. Pharmacol. 2015, 172, 6024-6109. [CrossRef] 
11. Park, S.J.; Ahmad, F.; Philp, A.; Baar, K.; Williams, T.; Luo, H.; Ke, H.; Rehmann, H.; Taussig, R.; Brown, A.L.; et al. Resveratrol ameliorates aging-related metabolic phenotypes by inhibiting cAMP phosphodiesterases. Cell 2012, 148, 421-433. [CrossRef] [PubMed]

12. Liu, B.; Ghosh, S.; Yang, X.; Zheng, H.; Liu, X.; Wang, Z.; Jin, G.; Zheng, B.; Kennedy, B.K.; Suh, Y.; et al. Resveratrol rescues SIRT1-dependent adult stem cell decline and alleviates progeroid features in laminopathy-based progeria. Cell Metab. 2012, 16, 738-750. [CrossRef]

13. Csiszar, A.; Labinskyy, N.; Pinto, J.T.; Ballabh, P.; Zhang, H.; Losonczy, G.; Pearson, K.; de Cabo, R.; Pacher, P.; Zhang, C.; et al. Resveratrol induces mitochondrial biogenesis in endothelial cells. Am. J. Physiol. Heart Circ. Physiol. 2009, 297, H13-H20. [CrossRef] [PubMed]

14. Xia, N.; Strand, S.; Schlufter, F.; Siuda, D.; Reifenberg, G.; Kleinert, H.; Forstermann, U.; Li, H. Role of SIRT1 and FOXO factors in eNOS transcriptional activation by resveratrol. Nitric Oxide 2013, 32, 29-35. [CrossRef] [PubMed]

15. Xia, N.; Daiber, A.; Forstermann, U.; Li, H. Antioxidant effects of resveratrol in the cardiovascular system. Br. J. Pharmacol. 2017, 174, 1633-1646. [CrossRef] [PubMed]

16. Ungvari, Z.; Bagi, Z.; Feher, A.; Recchia, F.A.; Sonntag, W.E.; Pearson, K.; de Cabo, R.; Csiszar, A. Resveratrol confers endothelial protection via activation of the antioxidant transcription factor Nrf2. Am. J. Physiol. Heart Circ. Physiol. 2010, 299, H18-H24. [CrossRef]

17. Hawley, S.A.; Ross, F.A.; Chevtzoff, C.; Green, K.A.; Evans, A.; Fogarty, S.; Towler, M.C.; Brown, L.J.; Ogunbayo, O.A.; Evans, A.M.; et al. Use of cells expressing gamma subunit variants to identify diverse mechanisms of AMPK activation. Cell Metab. 2010, 11, 554-565. [CrossRef]

18. Dasgupta, B.; Milbrandt, J. Resveratrol stimulates AMP kinase activity in neurons. Proc. Natl. Acad. Sci. USA 2007, 104, 7217-7222. [CrossRef]

19. Hou, X.; Xu, S.; Maitland-Toolan, K.A.; Sato, K.; Jiang, B.; Ido, Y.; Lan, F.; Walsh, K.; Wierzbicki, M.; Verbeuren, T.J.; et al. SIRT1 regulates hepatocyte lipid metabolism through activating AMP-activated protein kinase. J. Biol. Chem. 2008, 283, 20015-20026. [CrossRef]

20. Lan, F.; Cacicedo, J.M.; Ruderman, N.; Ido, Y. SIRT1 modulation of the acetylation status, cytosolic localization, and activity of LKB1. Possible role in AMP-activated protein kinase activation. J. Biol. Chem. 2008, 283, 27628-27635. [CrossRef]

21. Ruderman, N.B.; Xu, X.J.; Nelson, L.; Cacicedo, J.M.; Saha, A.K.; Lan, F.; Ido, Y. AMPK and SIRT1: A long-standing partnership? Am. J. Physiol. Endocrinol. Metab. 2010, 298, E751-E760. [CrossRef]

22. Haigis, M.C.; Sinclair, D.A. Mammalian sirtuins: Biological insights and disease relevance. Annu. Rev. Pathol. 2010, 5, 253-295. [CrossRef]

23. Bowers, J.L.; Tyulmenkov, V.V.; Jernigan, S.C.; Klinge, C.M. Resveratrol acts as a mixed agonist/antagonist for estrogen receptors alpha and beta. Endocrinology 2000, 141, 3657-3667. [CrossRef]

24. Klinge, C.M.; Blankenship, K.A.; Risinger, K.E.; Bhatnagar, S.; Noisin, E.L.; Sumanasekera, W.K.; Zhao, L.; Brey, D.M.; Keynton, R.S. Resveratrol and estradiol rapidly activate MAPK signaling through estrogen receptors alpha and beta in endothelial cells. J. Biol. Chem. 2005, 280, 7460-7468. [CrossRef]

25. Klinge, C.M.; Wickramasinghe, N.S.; Ivanova, M.M.; Dougherty, S.M. Resveratrol stimulates nitric oxide production by increasing estrogen receptor alpha-Src-caveolin-1 interaction and phosphorylation in human umbilical vein endothelial cells. FASEB J. 2008, 22, 2185-2197. [CrossRef]

26. Yu, H.P.; Hwang, T.L.; Hwang, T.L.; Yen, C.H.; Lau, Y.T. Resveratrol prevents endothelial dysfunction and aortic superoxide production after trauma hemorrhage through estrogen receptor-dependent hemeoxygenase-1 pathway. Crit. Care Med. 2010, 38, 1147-1154. [CrossRef]

27. Nagaoka, T.; Hein, T.W.; Yoshida, A.; Kuo, L. Resveratrol, a component of red wine, elicits dilation of isolated porcine retinal arterioles: Role of nitric oxide and potassium channels. Investig. Ophthalmol. Vis. Sci. 2007, 48, 4232-4239. [CrossRef]

28. Gojkovic-Bukarica, L.; Novakovic, A.; Kanjuh, V.; Bumbasirevic, M.; Lesic, A.; Heinle, H. A role of ion channels in the endothelium-independent relaxation of rat mesenteric artery induced by resveratrol. J. Pharmacol. Sci. 2008, 108, 124-130. [CrossRef]

29. Protic, D.; Radunovic, N.; Spremovic-Radenovic, S.; Zivanovic, V.; Heinle, H.; Petrovic, A.; Gojkovic-Bukarica, L. The Role of Potassium Channels in the Vasodilatation Induced by Resveratrol and Naringenin in Isolated Human Umbilical Vein. Drug. Dev. Res. 2015, 76, 17-23. [CrossRef] 
30. Kim, T.T.; Parajuli, N.; Sung, M.M.; Bairwa, S.C.; Levasseur, J.; Soltys, C.M.; Wishart, D.S.; Madsen, K.; Schertzer, J.D.; Dyck, J.R.B. Fecal transplant from resveratrol-fed donors improves glycaemia and cardiovascular features of the metabolic syndrome in mice. Am. J. Physiol. Endocrinol. Metab. 2018, 315, E511-E519. [CrossRef]

31. Chaplin, A.; Carpene, C.; Mercader, J. Resveratrol, Metabolic Syndrome, and Gut Microbiota. Nutrients 2018, 10, 1651. [CrossRef]

32. Park, I.; Lee, Y.; Kim, H.D.; Kim, K. Effect of Resveratrol, a SIRT1 Activator, on the Interactions of the CLOCK/BMAL1 Complex. Endocrinol. Metab. 2014, 29, 379-387. [CrossRef]

33. Nicholson, S.K.; Tucker, G.A.; Brameld, J.M. Effects of dietary polyphenols on gene expression in human vascular endothelial cells. Proc. Nutr. Soc. 2008, 67, 42-47. [CrossRef]

34. Li, H.; Forstermann, U. Nitric oxide in the pathogenesis of vascular disease. J. Pathol. 2000, 190, $244-254$. [CrossRef]

35. Li, H.; Wallerath, T.; Forstermann, U. Physiological mechanisms regulating the expression of endothelial-type NO synthase. Nitric Oxide 2002, 7, 132-147. [CrossRef]

36. Zhao, Y.; Vanhoutte, P.M.; Leung, S.W. Vascular nitric oxide: Beyond eNOS. J. Pharmacol. Sci. 2015, 129, 83-94. [CrossRef]

37. Li, H.; Forstermann, U. Prevention of atherosclerosis by interference with the vascular nitric oxide system. Curr. Pharm. Des. 2009, 15, 3133-3145. [CrossRef]

38. Forstermann, U.; Xia, N.; Li, H. Roles of Vascular Oxidative Stress and Nitric Oxide in the Pathogenesis of Atherosclerosis. Circ. Res. 2017, 120, 713-735. [CrossRef]

39. Li, H.; Horke, S.; Forstermann, U. Vascular oxidative stress, nitric oxide and atherosclerosis. Atherosclerosis 2014, 237, 208-219. [CrossRef]

40. Huang, P.L.; Huang, Z.; Mashimo, H.; Bloch, K.D.; Moskowitz, M.A.; Bevan, J.A.; Fishman, M.C. Hypertension in mice lacking the gene for endothelial nitric oxide synthase. Nature 1995, 377, 239-242. [CrossRef]

41. Kuhlencordt, P.J.; Gyurko, R.; Han, F.; Scherrer-Crosbie, M.; Aretz, T.H.; Hajjar, R.; Picard, M.H.; Huang, P.L. Accelerated atherosclerosis, aortic aneurysm formation, and ischemic heart disease in apolipoprotein E/endothelial nitric oxide synthase double-knockout mice. Circulation 2001, 104, 448-454. [CrossRef]

42. Liu, V.W.; Huang, P.L. Cardiovascular roles of nitric oxide: A review of insights from nitric oxide synthase gene disrupted mice. Cardiovasc. Res. 2008, 77, 19-29. [CrossRef] [PubMed]

43. Nisoli, E.; Tonello, C.; Cardile, A.; Cozzi, V.; Bracale, R.; Tedesco, L.; Falcone, S.; Valerio, A.; Cantoni, O.; Clementi, E.; et al. Calorie restriction promotes mitochondrial biogenesis by inducing the expression of eNOS. Science 2005, 310, 314-317. [CrossRef]

44. Duplain, H.; Burcelin, R.; Sartori, C.; Cook, S.; Egli, M.; Lepori, M.; Vollenweider, P.; Pedrazzini, T.; Nicod, P.; Thorens, B.; et al. Insulin resistance, hyperlipidemia, and hypertension in mice lacking endothelial nitric oxide synthase. Circulation 2001, 104, 342-345. [CrossRef]

45. Sansbury, B.E.; Cummins, T.D.; Tang, Y.; Hellmann, J.; Holden, C.R.; Harbeson, M.A.; Chen, Y.; Patel, R.P.; Spite, M.; Bhatnagar, A.; et al. Overexpression of endothelial nitric oxide synthase prevents diet-induced obesity and regulates adipocyte phenotype. Circ. Res. 2012, 111, 1176-1189. [CrossRef]

46. Xia, N.; Forstermann, U.; Li, H. Resveratrol and endothelial nitric oxide. Molecules 2014, 19, $16102-16121$. [CrossRef]

47. Li, H.; Wallerath, T.; Munzel, T.; Forstermann, U. Regulation of endothelial-type NO synthase expression in pathophysiology and in response to drugs. Nitric Oxide 2002, 7, 149-164. [CrossRef]

48. Wallerath, T.; Deckert, G.; Ternes, T.; Anderson, H.; Li, H.; Witte, K.; Forstermann, U. Resveratrol, a polyphenolic phytoalexin present in red wine, enhances expression and activity of endothelial nitric oxide synthase. Circulation 2002, 106, 1652-1658. [CrossRef]

49. Wallerath, T.; Poleo, D.; Li, H.; Forstermann, U. Red wine increases the expression of human endothelial nitric oxide synthase: A mechanism that may contribute to its beneficial cardiovascular effects. J. Am. Coll. Cardiol. 2003, 41, 471-478. [CrossRef]

50. Wallerath, T.; Li, H.; Godtel-Ambrust, U.; Schwarz, P.M.; Forstermann, U. A blend of polyphenolic compounds explains the stimulatory effect of red wine on human endothelial NO synthase. Nitric Oxide 2005, 12, 97-104. [CrossRef] 
51. Zhang, Q.J.; Wang, Z.; Chen, H.Z.; Zhou, S.; Zheng, W.; Liu, G.; Wei, Y.S.; Cai, H.; Liu, D.P.; Liang, C.C. Endothelium-specific overexpression of class III deacetylase SIRT1 decreases atherosclerosis in apolipoprotein E-deficient mice. Cardiovasc. Res. 2008, 80, 191-199. [CrossRef]

52. Fleming, I. Molecular mechanisms underlying the activation of eNOS. Pflugers Arch. 2010, 459, $793-806$. [CrossRef]

53. Heiss, E.H.; Dirsch, V.M. Regulation of eNOS enzyme activity by posttranslational modification. Curr. Pharm. Des. 2014, 20, 3503-3513. [CrossRef] [PubMed]

54. Xu, Q.; Hao, X.; Yang, Q.; Si, L. Resveratrol prevents hyperglycemia-induced endothelial dysfunction via activation of adenosine monophosphate-activated protein kinase. Biochem. Biophys. Res. Commun. 2009, 388, 389-394. [CrossRef] [PubMed]

55. Carrizzo, A.; Puca, A.; Damato, A.; Marino, M.; Franco, E.; Pompeo, F.; Traficante, A.; Civitillo, F.; Santini, L.; Trimarco, V.; et al. Resveratrol improves vascular function in patients with hypertension and dyslipidemia by modulating NO metabolism. Hypertension 2013, 62, 359-366. [CrossRef] [PubMed]

56. Mattagajasingh, I.; Kim, C.S.; Naqvi, A.; Yamamori, T.; Hoffman, T.A.; Jung, S.B.; DeRicco, J.; Kasuno, K.; Irani, K. SIRT1 promotes endothelium-dependent vascular relaxation by activating endothelial nitric oxide synthase. Proc. Natl. Acad. Sci. USA 2007, 104, 14855-14860. [CrossRef]

57. Arunachalam, G.; Yao, H.; Sundar, I.K.; Caito, S.; Rahman, I. SIRT1 regulates oxidant- and cigarette smoke-induced eNOS acetylation in endothelial cells: Role of resveratrol. Biochem. Biophys. Res. Commun. 2010, 393, 66-72. [CrossRef] [PubMed]

58. Maas, R.; Boger, R.; Luneburg, N. ADMA and the role of the genes: Lessons from genetically modified animals and human gene polymorphisms. Pharmacol. Res. 2009, 60, 475-480. [CrossRef]

59. Frombaum, M.; Therond, P.; Djelidi, R.; Beaudeux, J.L.; Bonnefont-Rousselot, D.; Borderie, D. Piceatannol is more effective than resveratrol in restoring endothelial cell dimethylarginine dimethylaminohydrolase expression and activity after high-glucose oxidative stress. Free Radic. Res. 2011, 45, 293-302. [CrossRef]

60. Feron, O.; Dessy, C.; Moniotte, S.; Desager, J.P.; Balligand, J.L. Hypercholesterolemia decreases nitric oxide production by promoting the interaction of caveolin and endothelial nitric oxide synthase. J. Clin. Investig. 1999, 103, 897-905. [CrossRef]

61. Tian, C.; Zhang, R.; Ye, X.; Zhang, C.; Jin, X.; Yamori, Y.; Hao, L.; Sun, X.; Ying, C. Resveratrol ameliorates high-glucose-induced hyperpermeability mediated by caveolae via VEGF/KDR pathway. Genes Nutr. 2013, 8, 231-239. [CrossRef] [PubMed]

62. Penumathsa, S.V.; Koneru, S.; Samuel, S.M.; Maulik, G.; Bagchi, D.; Yet, S.F.; Menon, V.P.; Maulik, N. Strategic targets to induce neovascularization by resveratrol in hypercholesterolemic rat myocardium: Role of caveolin-1, endothelial nitric oxide synthase, hemeoxygenase-1, and vascular endothelial growth factor. Free Radic. Biol. Med. 2008, 45, 1027-1034. [CrossRef]

63. Penumathsa, S.V.; Thirunavukkarasu, M.; Zhan, L.; Maulik, G.; Menon, V.P.; Bagchi, D.; Maulik, N. Resveratrol enhances GLUT-4 translocation to the caveolar lipid raft fractions through AMPK/Akt/eNOS signalling pathway in diabetic myocardium. J. Cell. Mol. Med. 2008, 12, 2350-2361. [CrossRef]

64. Forstermann, U.; Munzel, T. Endothelial nitric oxide synthase in vascular disease: From marvel to menace. Circulation 2006, 113, 1708-1714. [CrossRef] [PubMed]

65. Li, H.; Forstermann, U. Pharmacological Prevention of eNOS Uncoupling. Curr. Pharm. Des. 2014, 20, 3595-3606. [CrossRef]

66. Li, H.; Forstermann, U. Uncoupling of endothelial NO synthase in atherosclerosis and vascular disease. Curr. Opin. Pharmacol. 2013, 13, 161-167. [CrossRef]

67. Laursen, J.B.; Somers, M.; Kurz, S.; McCann, L.; Warnholtz, A.; Freeman, B.A.; Tarpey, M.; Fukai, T.; Harrison, D.G. Endothelial regulation of vasomotion in apoE-deficient mice: Implications for interactions between peroxynitrite and tetrahydrobiopterin. Circulation 2001, 103, 1282-1288. [CrossRef] [PubMed]

68. Landmesser, U.; Dikalov, S.; Price, S.R.; McCann, L.; Fukai, T.; Holland, S.M.; Mitch, W.E.; Harrison, D.G. Oxidation of tetrahydrobiopterin leads to uncoupling of endothelial cell nitric oxide synthase in hypertension. J. Clin. Investig. 2003, 111, 1201-1209. [CrossRef] [PubMed]

69. Alp, N.J.; McAteer, M.A.; Khoo, J.; Choudhury, R.P.; Channon, K.M. Increased endothelial tetrahydrobiopterin synthesis by targeted transgenic GTP-cyclohydrolase I overexpression reduces endothelial dysfunction and atherosclerosis in ApoE-knockout mice. Arterioscler. Thromb. Vasc. Biol. 2004, 24, 445-450. [CrossRef] [PubMed] 
70. Zou, M.H.; Shi, C.; Cohen, R.A. Oxidation of the zinc-thiolate complex and uncoupling of endothelial nitric oxide synthase by peroxynitrite. J. Clin. Investig. 2002, 109, 817-826. [CrossRef] [PubMed]

71. Xia, N.; Daiber, A.; Habermeier, A.; Closs, E.I.; Thum, T.; Spanier, G.; Lu, Q.; Oelze, M.; Torzewski, M.; Lackner, K.J.; et al. Resveratrol reverses endothelial nitric-oxide synthase uncoupling in apolipoprotein $\mathrm{E}$ knockout mice. J. Pharmacol. Exp. Ther. 2010, 335, 149-154. [CrossRef]

72. Liu, J.C.; Chen, J.J.; Chan, P.; Cheng, C.F.; Cheng, T.H. Inhibition of cyclic strain-induced endothelin-1 gene expression by resveratrol. Hypertension 2003, 42, 1198-1205. [CrossRef] [PubMed]

73. Spanier, G.; Xu, H.; Xia, N.; Tobias, S.; Deng, S.; Wojnowski, L.; Forstermann, U.; Li, H. Resveratrol reduces endothelial oxidative stress by modulating the gene expression of superoxide dismutase 1 (SOD1), glutathione peroxidase 1 (GPx1) and NADPH oxidase subunit (Nox4). J. Physiol. Pharmacol. 2009, 60 (Suppl. 4), 111-116.

74. Ungvari, Z.; Orosz, Z.; Rivera, A.; Labinskyy, N.; Xiangmin, Z.; Olson, S.; Podlutsky, A.; Csiszar, A. Resveratrol increases vascular oxidative stress resistance. Am. J. Physiol. Heart Circ. Physiol. 2007, 292, H2417-H2424. [CrossRef]

75. Ungvari, Z.; Labinskyy, N.; Mukhopadhyay, P.; Pinto, J.T.; Bagi, Z.; Ballabh, P.; Zhang, C.; Pacher, P.; Csiszar, A. Resveratrol attenuates mitochondrial oxidative stress in coronary arterial endothelial cells. Am. J. Physiol. Heart Circ. Physiol. 2009, 297, H1876-H1881. [CrossRef]

76. Xia, N.; Forstermann, U.; Li, H. Resveratrol as a gene regulator in the vasculature. Curr. Pharm. Biotechnol. 2014, 15, 401-408. [CrossRef]

77. Corder, R.; Douthwaite, J.A.; Lees, D.M.; Khan, N.Q.; Viseu Dos Santos, A.C.; Wood, E.G.; Carrier, M.J. Endothelin-1 synthesis reduced by red wine. Nature 2001, 414, 863-864. [CrossRef]

78. Zou, J.G.; Wang, Z.R.; Huang, Y.Z.; Cao, K.J.; Wu, J.M. Effect of red wine and wine polyphenol resveratrol on endothelial function in hypercholesterolemic rabbits. Int. J. Mol. Med. 2003, 11, 317-320. [CrossRef]

79. Nicholson, S.K.; Tucker, G.A.; Brameld, J.M. Physiological concentrations of dietary polyphenols regulate vascular endothelial cell expression of genes important in cardiovascular health. Br. J. Nutr. 2010, 103, 1398-1403. [CrossRef]

80. Coppa, T.; Lazze, M.C.; Cazzalini, O.; Perucca, P.; Pizzala, R.; Bianchi, L.; Stivala, L.A.; Forti, L.; Maccario, C.; Vannini, V.; et al. Structure-activity relationship of resveratrol and its analogue, 4,4'-dihydroxy-trans-stilbene, toward the endothelin axis in human endothelial cells. J. Med. Food 2011, 14, 1173-1180. [CrossRef] [PubMed]

81. Ruef, J.; Moser, M.; Kubler, W.; Bode, C. Induction of endothelin-1 expression by oxidative stress in vascular smooth muscle cells. Cardiovasc. Pathol. 2001, 10, 311-315. [CrossRef]

82. Chao, H.H.; Juan, S.H.; Liu, J.C.; Yang, H.Y.; Yang, E.; Cheng, T.H.; Shyu, K.G. Resveratrol inhibits angiotensin II-induced endothelin-1 gene expression and subsequent proliferation in rat aortic smooth muscle cells. Eur. J. Pharmacol. 2005, 515, 1-9. [CrossRef]

83. Juan, S.H.; Cheng, T.H.; Lin, H.C.; Chu, Y.L.; Lee, W.S. Mechanism of concentration-dependent induction of heme oxygenase-1 by resveratrol in human aortic smooth muscle cells. Biochem. Pharmacol. 2005, 69, 41-48. [CrossRef]

84. Kim, J.W.; Lim, S.C.; Lee, M.Y.; Lee, J.W.; Oh, W.K.; Kim, S.K.; Kang, K.W. Inhibition of neointimal formation by trans-resveratrol: Role of phosphatidyl inositol 3-kinase-dependent Nrf2 activation in heme oxygenase-1 induction. Mol. Nutr. Food Res. 2010, 54, 1497-1505. [CrossRef]

85. Li, Y.; Cao, Z.; Zhu, H. Upregulation of endogenous antioxidants and phase 2 enzymes by the red wine polyphenol, resveratrol in cultured aortic smooth muscle cells leads to cytoprotection against oxidative and electrophilic stress. Pharmacol. Res. 2006, 53, 6-15. [CrossRef] [PubMed]

86. Thompson, A.M.; Martin, K.A.; Rzucidlo, E.M. Resveratrol induces vascular smooth muscle cell differentiation through stimulation of SirT1 and AMPK. PLoS ONE 2014, 9, e85495. [CrossRef]

87. Wang, D.; Uhrin, P.; Mocan, A.; Waltenberger, B.; Breuss, J.M.; Tewari, D.; Mihaly-Bison, J.; Huminiecki, L.; Starzynski, R.R.; Tzvetkov, N.T.; et al. Vascular smooth muscle cell proliferation as a therapeutic target. Part 1: Molecular targets and pathways. Biotechnol. Adv. 2018, 36, 1586-1607. [CrossRef] [PubMed]

88. Ong, E.T.; Hwang, T.L.; Huang, Y.L.; Lin, C.F.; Wu, W.B. Vitisin B, a resveratrol tetramer, inhibits migration through inhibition of PDGF signaling and enhancement of cell adhesiveness in cultured vascular smooth muscle cells. Toxicol. Appl. Pharmacol. 2011, 256, 198-208. [CrossRef] [PubMed]

89. Park, E.S.; Lim, Y.; Hong, J.T.; Yoo, H.S.; Lee, C.K.; Pyo, M.Y.; Yun, Y.P. Pterostilbene, a natural dimethylated analog of resveratrol, inhibits rat aortic vascular smooth muscle cell proliferation by blocking Akt-dependent pathway. Vascul. Pharmacol. 2010, 53, 61-67. [CrossRef] 
90. Khandelwal, A.R.; Hebert, V.Y.; Kleinedler, J.J.; Rogers, L.K.; Ullevig, S.L.; Asmis, R.; Shi, R.; Dugas, T.R. Resveratrol and quercetin interact to inhibit neointimal hyperplasia in mice with a carotid injury. J. Nutr. 2012, 142, 1487-1494. [CrossRef]

91. Orozco-Sevilla, V.; Naftalovich, R.; Hoffmann, T.; London, D.; Czernizer, E.; Yang, C.; Dardik, A.; Dardik, H. Epigallocatechin-3-gallate is a potent phytochemical inhibitor of intimal hyperplasia in the wire-injured carotid artery. J. Vasc. Surg. 2013, 58, 1360-1365. [CrossRef]

92. Kleinedler, J.J.; Foley, J.D.; Orchard, E.A.; Dugas, T.R. Novel nanocomposite stent coating releasing resveratrol and quercetin reduces neointimal hyperplasia and promotes re-endothelialization. J. Control. Release 2012, 159, 27-33. [CrossRef] [PubMed]

93. Zhu, Y.; Takayama, T.; Wang, B.; Kent, A.; Zhang, M.; Binder, B.Y.; Urabe, G.; Shi, Y.; DiRenzo, D.; Goel, S.A.; et al. Restenosis Inhibition and Re-differentiation of TGFbeta/Smad3-activated Smooth Muscle Cells by Resveratrol. Sci. Rep. 2017, 7, 41916. [CrossRef] [PubMed]

94. Zou, J.; Huang, Y.; Chen, Q.; Wang, N.; Cao, K.; Hsieh, T.C.; Wu, J.M. Suppression of mitogenesis and regulation of cell cycle traverse by resveratrol in cultured smooth muscle cells. Int. J. Oncol. 1999, 15, 647-651. [CrossRef] [PubMed]

95. Mizutani, K.; Ikeda, K.; Yamori, Y. Resveratrol inhibits AGEs-induced proliferation and collagen synthesis activity in vascular smooth muscle cells from stroke-prone spontaneously hypertensive rats. Biochem. Biophys. Res. Commun. 2000, 274, 61-67. [CrossRef]

96. Haider, U.G.; Sorescu, D.; Griendling, K.K.; Vollmar, A.M.; Dirsch, V.M. Resveratrol suppresses angiotensin II-induced Akt/protein kinase B and p70 S6 kinase phosphorylation and subsequent hypertrophy in rat aortic smooth muscle cells. Mol. Pharmacol. 2002, 62, 772-777. [CrossRef] [PubMed]

97. Mnjoyan, Z.H.; Fujise, K. Profound negative regulatory effects by resveratrol on vascular smooth muscle cells: A role of p53-p21(WAF1/CIP1) pathway. Biochem. Biophys. Res. Commun. 2003, 311, 546-552. [CrossRef]

98. Haider, U.G.; Sorescu, D.; Griendling, K.K.; Vollmar, A.M.; Dirsch, V.M. Resveratrol increases serine15-phosphorylated but transcriptionally impaired p53 and induces a reversible DNA replication block in serum-activated vascular smooth muscle cells. Mol. Pharmacol. 2003, 63, 925-932. [CrossRef]

99. Poussier, B.; Cordova, A.C.; Becquemin, J.P.; Sumpio, B.E. Resveratrol inhibits vascular smooth muscle cell proliferation and induces apoptosis. J. Vasc. Surg. 2005, 42, 1190-1197. [CrossRef]

100. Lee, B.; Moon, S.K. Resveratrol inhibits TNF-alpha-induced proliferation and matrix metalloproteinase expression in human vascular smooth muscle cells. J. Nutr. 2005, 135, 2767-2773. [CrossRef]

101. Wang, Z.; Chen, Y.; Labinskyy, N.; Hsieh, T.C.; Ungvari, Z.; Wu, J.M. Regulation of proliferation and gene expression in cultured human aortic smooth muscle cells by resveratrol and standardized grape extracts. Biochem. Biophys. Res. Commun. 2006, 346, 367-376. [CrossRef]

102. Brito, P.M.; Devillard, R.; Negre-Salvayre, A.; Almeida, L.M.; Dinis, T.C.; Salvayre, R.; Auge, N. Resveratrol inhibits the mTOR mitogenic signaling evoked by oxidized LDL in smooth muscle cells. Atherosclerosis 2009, 205, 126-134. [CrossRef] [PubMed]

103. Choi, K.H.; Kim, J.E.; Song, N.R.; Son, J.E.; Hwang, M.K.; Byun, S.; Kim, J.H.; Lee, K.W.; Lee, H.J. Phosphoinositide 3-kinase is a novel target of piceatannol for inhibiting PDGF-BB-induced proliferation and migration in human aortic smooth muscle cells. Cardiovasc. Res. 2010, 85, 836-844. [CrossRef] [PubMed]

104. Fry, J.L.; Al Sayah, L.; Weisbrod, R.M.; Van Roy, I.; Weng, X.; Cohen, R.A.; Bachschmid, M.M.; Seta, F. Vascular Smooth Muscle Sirtuin-1 Protects Against Diet-Induced Aortic Stiffness. Hypertension 2016, 68, 775-784. [CrossRef] [PubMed]

105. Miyazaki, R.; Ichiki, T.; Hashimoto, T.; Inanaga, K.; Imayama, I.; Sadoshima, J.; Sunagawa, K. SIRT1, a longevity gene, downregulates angiotensin II type 1 receptor expression in vascular smooth muscle cells. Arterioscler. Thromb. Vasc. Biol. 2008, 28, 1263-1269. [CrossRef] [PubMed]

106. Jang, I.A.; Kim, E.N.; Lim, J.H.; Kim, M.Y.; Ban, T.H.; Yoon, H.E.; Park, C.W.; Chang, Y.S.; Choi, B.S. Effects of Resveratrol on the Renin-Angiotensin System in the Aging Kidney. Nutrients 2018, 10, 1741. [CrossRef] [PubMed]

107. Kim, E.N.; Kim, M.Y.; Lim, J.H.; Kim, Y.; Shin, S.J.; Park, C.W.; Kim, Y.S.; Chang, Y.S.; Yoon, H.E.; Choi, B.S. The protective effect of resveratrol on vascular aging by modulation of the renin-angiotensin system. Atherosclerosis 2018, 270, 123-131. [CrossRef] [PubMed]

108. Gresele, P.; Cerletti, C.; Guglielmini, G.; Pignatelli, P.; de Gaetano, G.; Violi, F. Effects of resveratrol and other wine polyphenols on vascular function: An update. J. Nutr. Biochem. 2011, 22, 201-211. [CrossRef] 
109. Rotondo, S.; Rajtar, G.; Manarini, S.; Celardo, A.; Rotillo, D.; de Gaetano, G.; Evangelista, V.; Cerletti, C. Effect of trans-resveratrol, a natural polyphenolic compound, on human polymorphonuclear leukocyte function. Br. J. Pharmacol. 1998, 123, 1691-1699. [CrossRef] [PubMed]

110. Cullen, J.P.; Morrow, D.; Jin, Y.; von Offenberg Sweeney, N.; Sitzmann, J.V.; Cahill, P.A.; Redmond, E.M. Resveratrol inhibits expression and binding activity of the monocyte chemotactic protein-1 receptor, CCR2, on THP-1 monocytes. Atherosclerosis 2007, 195, e125-e133. [CrossRef]

111. Li, Q.; Huyan, T.; Ye, L.J.; Li, J.; Shi, J.L.; Huang, Q.S. Concentration-dependent biphasic effects of resveratrol on human natural killer cells in vitro. J. Agric. Food Chem. 2014, 62, 10928-10935. [CrossRef]

112. Pendurthi, U.R.; Williams, J.T.; Rao, L.V. Resveratrol, a polyphenolic compound found in wine, inhibits tissue factor expression in vascular cells: A possible mechanism for the cardiovascular benefits associated with moderate consumption of wine. Arterioscler. Thromb. Vasc. Biol. 1999, 19, 419-426. [CrossRef]

113. Ferrero, M.E.; Bertelli, A.E.; Fulgenzi, A.; Pellegatta, F.; Corsi, M.M.; Bonfrate, M.; Ferrara, F.; De Caterina, R.; Giovannini, L.; Bertelli, A. Activity in vitro of resveratrol on granulocyte and monocyte adhesion to endothelium. Am. J. Clin. Nutr. 1998, 68, 1208-1214. [CrossRef]

114. Guo, R.; Liu, B.; Wang, K.; Zhou, S.; Li, W.; Xu, Y. Resveratrol ameliorates diabetic vascular inflammation and macrophage infiltration in $\mathrm{db} / \mathrm{db}$ mice by inhibiting the NF-kappaB pathway. Diab. Vasc. Dis. Res. 2014, 11, 92-102. [CrossRef]

115. Xia, N.; Li, H. The role of perivascular adipose tissue in obesity-induced vascular dysfunction. Br. J. Pharmacol. 2017, 174, 3425-3442. [CrossRef]

116. Xia, N.; Forstermann, U.; Li, H. Effects of resveratrol on eNOS in the endothelium and the perivascular adipose tissue. Ann. N. Y. Acad. Sci. 2017, 1403, 132-141. [CrossRef]

117. Xia, N.; Horke, S.; Habermeier, A.; Closs, E.I.; Reifenberg, G.; Gericke, A.; Mikhed, Y.; Munzel, T.; Daiber, A.; Forstermann, U.; et al. Uncoupling of Endothelial Nitric Oxide Synthase in Perivascular Adipose Tissue of Diet-Induced Obese Mice. Arterioscler. Thromb. Vasc. Biol. 2016, 36, 78-85. [CrossRef]

118. Xia, N.; Weisenburger, S.; Koch, E.; Burkart, M.; Reifenberg, G.; Forstermann, U.; Li, H. Restoration of perivascular adipose tissue function in diet-induced obese mice without changing bodyweight. Br. J. Pharmacol. 2017, 174, 3443-3453. [CrossRef]

119. Sun, Y.; Li, J.; Xiao, N.; Wang, M.; Kou, J.; Qi, L.; Huang, F.; Liu, B.; Liu, K. Pharmacological activation of AMPK ameliorates perivascular adipose/endothelial dysfunction in a manner interdependent on AMPK and SIRT1. Pharmacol. Res. 2014, 89, 19-28. [CrossRef]

120. Chen, Y.; Xu, X.; Zhang, Y.; Liu, K.; Huang, F.; Liu, B.; Kou, J. Diosgenin regulates adipokine expression in perivascular adipose tissue and ameliorates endothelial dysfunction via regulation of AMPK. J. Steroid Biochem. Mol. Biol. 2016, 155 Pt A, 155-165. [CrossRef]

121. Zordoky, B.N.; Robertson, I.M.; Dyck, J.R. Preclinical and clinical evidence for the role of resveratrol in the treatment of cardiovascular diseases. Biochim. Biophys. Acta 2015, 1852, 1155-1177. [CrossRef]

122. Park, E.J.; Pezzuto, J.M. The pharmacology of resveratrol in animals and humans. Biochim. Biophys. Acta 2015, 1852, 1071-1113. [CrossRef] [PubMed]

123. Bhatt, S.R.; Lokhandwala, M.F.; Banday, A.A. Resveratrol prevents endothelial nitric oxide synthase uncoupling and attenuates development of hypertension in spontaneously hypertensive rats. Eur. J. Pharmacol. 2011, 667, 258-264. [CrossRef] [PubMed]

124. Dolinsky, V.W.; Chakrabarti, S.; Pereira, T.J.; Oka, T.; Levasseur, J.; Beker, D.; Zordoky, B.N.; Morton, J.S.; Nagendran, J.; Lopaschuk, G.D.; et al. Resveratrol prevents hypertension and cardiac hypertrophy in hypertensive rats and mice. Biochim. Biophys. Acta 2013, 1832, 1723-1733. [CrossRef] [PubMed]

125. Liu, Z.; Song, Y.; Zhang, X.; Liu, Z.; Zhang, W.; Mao, W.; Wang, W.; Cui, W.; Zhang, X.; Jia, X.; et al. Effects of trans-resveratrol on hypertension-induced cardiac hypertrophy using the partially nephrectomized rat model. Clin. Exp. Pharmacol. Physiol. 2005, 32, 1049-1054. [CrossRef] [PubMed]

126. Toklu, H.Z.; Sehirli, O.; Ersahin, M.; Suleymanoglu, S.; Yiginer, O.; Emekli-Alturfan, E.; Yarat, A.; Yegen, B.C.; Sener, G. Resveratrol improves cardiovascular function and reduces oxidative organ damage in the renal, cardiovascular and cerebral tissues of two-kidney, one-clip hypertensive rats. J. Pharm. Pharmacol. 2010, 62, 1784-1793. [CrossRef] [PubMed]

127. Chan, V.; Fenning, A.; Iyer, A.; Hoey, A.; Brown, L. Resveratrol improves cardiovascular function in DOCA-salt hypertensive rats. Curr. Pharm. Biotechnol. 2011, 12, 429-436. [CrossRef] [PubMed] 
128. Franco, J.G.; Lisboa, P.C.; Lima, N.S.; Amaral, T.A.; Peixoto-Silva, N.; Resende, A.C.; Oliveira, E.; Passos, M.C.; Moura, E.G. Resveratrol attenuates oxidative stress and prevents steatosis and hypertension in obese rats programmed by early weaning. J. Nutr. Biochem. 2013, 24, 960-966. [CrossRef]

129. Aubin, M.C.; Lajoie, C.; Clement, R.; Gosselin, H.; Calderone, A.; Perrault, L.P. Female rats fed a high-fat diet were associated with vascular dysfunction and cardiac fibrosis in the absence of overt obesity and hyperlipidemia: Therapeutic potential of resveratrol. J. Pharmacol. Exp. Ther. 2008, 325, 961-968. [CrossRef]

130. Miatello, R.; Vazquez, M.; Renna, N.; Cruzado, M.; Zumino, A.P.; Risler, N. Chronic administration of resveratrol prevents biochemical cardiovascular changes in fructose-fed rats. Am. J. Hypertens. 2005, 18, 864-870. [CrossRef]

131. Akar, F.; Uludag, O.; Aydin, A.; Aytekin, Y.A.; Elbeg, S.; Tuzcu, M.; Sahin, K. High-fructose corn syrup causes vascular dysfunction associated with metabolic disturbance in rats: Protective effect of resveratrol. Food Chem. Toxicol. 2012, 50, 2135-2141. [CrossRef] [PubMed]

132. Rivera, L.; Moron, R.; Zarzuelo, A.; Galisteo, M. Long-term resveratrol administration reduces metabolic disturbances and lowers blood pressure in obese Zucker rats. Biochem. Pharmacol. 2009, 77, 1053-1063. [CrossRef] [PubMed]

133. Mizutani, K.; Ikeda, K.; Kawai, Y.; Yamori, Y. Resveratrol attenuates ovariectomy-induced hypertension and bone loss in stroke-prone spontaneously hypertensive rats. J. Nutr. Sci. Vitaminol. 2000, 46, 78-83. [CrossRef] [PubMed]

(C) 2019 by the authors. Licensee MDPI, Basel, Switzerland. This article is an open access article distributed under the terms and conditions of the Creative Commons Attribution (CC BY) license (http://creativecommons.org/licenses/by/4.0/). 